\title{
Facilitating E-Commerce in Jordan: A Qualitative Analysis
}

\author{
Husam Yaseen ${ }^{1}$, Moh'd Alhusban ${ }^{2}$, Kate Dingley ${ }^{1}$, Amal Alhosban ${ }^{3}$ \\ ${ }^{1}$ School of Computing, University of Portsmouth \\ ${ }^{2}$ School of Media Arts and Technology, Southampton Solent University \\ ${ }^{3}$ Department of Computer Science, Engineering and Physics, University of Michigan Flint
}

\begin{abstract}
The current expansion of the internet in the developing countries has open the door to online entrepreneurs for more digital contributions. Jordan is no exception, recent years have shown that Jordanian online consumers are engaged in ecommerce transactions to a certain extent, especially in new forms of social media commerce, but despite the proportional utilization and participation, electronic commerce implementation is still lagging behind. Electronic commerce has enormous potential to succeed in Jordan, however, this success is destined to failure if not systemically investigated and facilitated to meet Jordanian consumers' needs and objectives. This paper explores the current barriers that hind the further development of electronic commerce in Jordan. The views and perceptions expressed within this paper have been collected from various online business stack holders in Jordan.
\end{abstract}

\section{Introduction}

The emergence of information and communications technology (ICT) have contributed to the rapid growth of electronic commerce [1]. The internet and electronic devices like mobile are the most notable tools of communication, entertainment, and business, they also enhanced online usage and penetration. The number of the worldwide internet users reached 3.6 billion in June 2016, covering about $50.1 \%$ of the world population [2]. Ecommerce and its applications become as the most important method that the businesses apply it in 21 st. century, raising enormous opportunities and challenges in various aspects [3].

Despite the various opportunity that e-commerce offers, E-commerce adoption has not reached its full potential in the developing countries [4], [5], [6]. Previous literature has explored the factors affecting e-commerce adoption by providing abundant evidence of several issues such as trust, lack of legal framework, lack of payment systems, the absence of government role and much more. Many studies have indicated that Jordan e-commerce penetration is strong as a developing country [7], [8], [9].

However, there are some challenges that have been a major hindrance to its development which influences the development of all supportive services, like postal and payment.

While existing literature focuses mainly on identifying e-commerce challenges from the technological perspective, the call for a study was needed to point out the role of key players in solving those challenges towards e-commerce development.

Therefore, this research intends to identify the level of government and stakeholder's involvement in facilitating e-commerce in Jordan. To achieve this, this research conducted semi-structured interviews with 12 participants from various agencies in the government and private sector. This paper will shed the light on the current practices of those agencies in facilitating e-commerce activities. Also, it will provide useful insights on some area of improvements to overcome some of the challenges facing e-commerce adoption.

\section{Research Methodology}

As this study initially involves exploratory research, a qualitative approach was adopted. A qualitative approach is suitable to discover and gain an in-depth understanding of the phenomena [10]. A semi-structure interview was designed based on previous research future direction conducted on evaluating e-commerce awareness [9]. This study seeks to investigate the role of government and stakeholders in facilitating e-commerce and their role in e-commerce awareness. The interviews consisted of three agencies (Finance, Delivery, and Government). A total of 12 interviews were conducted in July 2016. Table 1 illustrates the participated agencies. The participants were selected based on their role and involvement in e-commerce. Each interview in the study was contributed to the potential outcomes. The researcher led the interviews by posing open-ended questions and questions oriented towards e-commerce practices. 
Table 1. Interviews Participants

\begin{tabular}{|c|c|c|c|}
\hline Agency & Sector & Role & $\begin{array}{c}\text { Number of } \\
\text { Interviewees }\end{array}$ \\
\hline \multirow[t]{3}{*}{ Finance } & Bank A & $\begin{array}{c}\text { Branch } \\
\text { Manager }\end{array}$ & 1 \\
\hline & Bank B & $\begin{array}{c}\text { Digital } \\
\text { Marketing } \\
\text { Manager }\end{array}$ & 1 \\
\hline & Bank C & $\begin{array}{c}\text { Branch } \\
\text { Manager }\end{array}$ & 1 \\
\hline & $\begin{array}{l}\text { Payment } \\
\text { Gateway } \\
\end{array}$ & $\begin{array}{c}\text { Sales } \\
\text { Manager }\end{array}$ & 1 \\
\hline \multirow[t]{3}{*}{ Delivery } & $\begin{array}{l}\text { Delivery } \\
\text { Agent A }\end{array}$ & $\begin{array}{c}\text { Branch } \\
\text { Manager }\end{array}$ & 1 \\
\hline & $\begin{array}{l}\text { Delivery } \\
\text { Agent B }\end{array}$ & $\begin{array}{c}\text { Dispatched } \\
\text { officer }\end{array}$ & 1 \\
\hline & $\begin{array}{l}\text { Delivery } \\
\text { Agent C } \\
\end{array}$ & $\begin{array}{c}\text { Branch } \\
\text { Manager }\end{array}$ & 1 \\
\hline \multirow[t]{2}{*}{ Government } & Customs & N/A & 1 \\
\hline & Legislations & $\begin{array}{l}\text { Researchers } \\
\text { in E- } \\
\text { commerce } \\
\text { Law }\end{array}$ & 4 \\
\hline
\end{tabular}

After obtaining the required approval, the participants were asked to participate in the study. The researcher visited the participants on their workplace at a specific time. Each of the participants was interviewed individually. The duration of each interview conducted was between one hour and one hour and 30 minutes. The analysis of the interviews involved various steps. Firstly, the recorded interviews were transcribed and typed. This step was achieved by listening to the recordings, and transcript in Arabic and then translating the produced transcript into English. In total, the recorded interviews resulted in 62 pages of transcription in both Arabic and English. After the transcription and translation, each question was analysed separately for individual participants.

\section{Results and Discussion}

The study identified specific barriers hindering the adoption of e-commerce in Jordan. There is a wide range of reasons why e-commerce adoption in Jordan is hindered, see figure 1. for a framework of barriers hindering e-commerce adoption in Jordan. These reasons are most: lack of government support; lack of legislations; economic barriers (lack of payment systems, lack of postal services), socioculture barriers (lack of awareness).

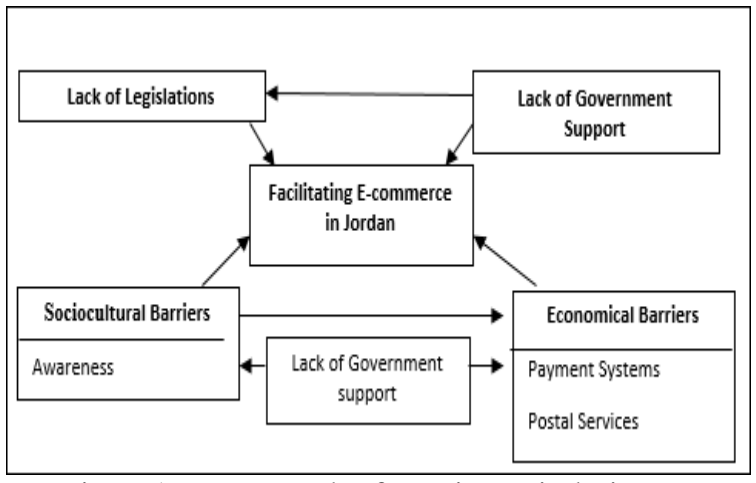

Figure1. Framework of Barriers Hindering ECommerce Adoption in Jordan

\subsection{Lack of Government Support}

The level of government support in e-commerce development is crucial for successful adoption especially in the developing countries [11]; [12]. By setting up the required IT infrastructure, it will affect the process of e-commerce development and inspire both public and private sectors to adopt e-commerce.

In the middle eastern countries, e-commerce implementation decisions are taken by the government. Therefore, its level of support will have an impact on the economic growth as the number of internet users are rapidly increasing [13]. Despite the advantages that e-commerce can offer, the government involvement in most of the middle eastern countries has not reached the desired expectations.

For example lack of government support was a significant barrier to e-commerce adoption in Oman [14], and Saudi Arabia [15]. The government in Jordan however, has proposed various initiatives to drive e-commerce development to the required level by providing guidance and support for the private sector [16]. Nevertheless, the Jordanian government has underestimated the impact of e-commerce on the economic growth by shifting its focus on the implementation of e-government programme. Consequently, this has prevented the successful spread of e-commerce and directed the research conducted in the field of e-commerce development toward e-government implementation.

Several scholars have investigated the government support of e-commerce development and have found that businesses who adopted e-commerce were perceived higher government support than nonadopters [13]; [17]; [18]; [19]; [20]; [21]. In Singapore, for example, the government support level was high enough to lead the country in ecommerce adoption, not only in their initiative towards e-commerce infrastructure but also in developing a strategic plan to increase the level of awareness among society [22].Therefore, the Jordanian government should plan strategies to achieve and raise national awareness of the Internet 
and e-commerce by providing a marketplace that complies with customers' needs, reducing the administration, operations costs, taxation, and increasing the investment in the ICT infrastructure [23]. Furthermore, previous studies have shown that some of the e-commerce challenges cannot be addressed without the government's support such as e-commerce legislations and awareness [24]. The Jordanian government is responsible for setting the e-commerce laws and facilitating other services like reducing taxation for products purchased online. An interviewee from Jordanian Customs department said: "Our role in e-commerce is quite important, and we understand the advantages of e-commerce to our economy growth. Therefore, for the products purchased online for 200JD and below, we have waved the customs tax to encourage customers to buy online". Consequently, government support plays an important role in e-commerce adoption and it has the potential to make a positive contribution to e-commerce development or more negatively to place barriers in the way [24].

\subsection{Lack of E-commerce Legislations}

\subsubsection{Jordan's' Electronic Transaction Law (ETL)}

Jordan became one of the first countries in the Middle East region to enact laws regarding ICT related transactions following the spread of internet use in the [25]. This legislation followed the realisation that the internet customers need to be protected because the internet poses fraud and mistake threats. Jordan introduced the Electronic Transaction Law (ETL) to provide legal backing for electronic transactions. However, it did not nullify other laws that already existed. Where there is a shortfall in the new law, traditional contracting laws are still applicable. The new ETL covers a wide area of internet transactions including computer information transactions, general sale of goods and services via the internet, and other inter-party transactions conducted online. The scope of the act applies to all business-related transactions and government or official institution approved transactions. Enforcement of the act requires that both parties agree that they are going to conduct their transactions online.

The Electronic Transaction Law (ELT) was firstly drafted in 2001/no.85, then it was modified in 2015/no.15. This Law covers both governmental and business related transactions. This law was endorsed to be a model online transaction law, which was adopted by the United Nations Commission on International Trade Law (UNCITRAL) in 1996. Its main purpose was to acknowledge the transactions which take place electronically with the same legal value of the traditional environment. However, there were no important for this law as the article no.102 in Jordanian law stated that, it is legal to conduct transactions or contracts by phone, fax, and other electronic means, and the Internet is part of these means.

\subsubsection{The Practicality of ETL}

Legislation of the ETL, however, did little to better protect or offer a legal basis to address legal issues compared to the already existing law. The model law that existed had provision to include any new emerging technology within its jurisdiction. In this case, the emergence of the internet and internetrelated businesses could be accommodated under the old law by adjusting some articles in the law. The new law did not protect the consumer in an internetbased transaction in the same way as a consumer in any other transaction conducted offline. The new law failed to address concerns of internet businesses which include increased threats of fraud and mistakes as compared to other traditional transactions. In this respect, the legal framework in Jordan is not adequate to ensure safe and convenient transactions over the internet and needs reviewing.

Researcher1: "The is a lack of the Jordanian ET legislation, as the legislator was only concerned to recognise all transactions which are conducted electronically are legal. However, the legislator was supposed to organise the transactions between traders and customers. On this basis, all the electronic commerce laws were formed, such as the $U K$ e-commerce law for 2002, the French $e$ commerce law and the European e-commerce directive law. These laws focused on customers, while the Jordanian law did not pay attention to this point as it mainly focused on recognising the legality of electronic businesses."

\subsubsection{Awareness of Legislations}

Awareness about legal aspect in e-commerce is vital. Customers and businesses need to be aware of the legality of conducting online activities. In addition, awareness about their legal protection is another crucial aspect. Failing to do so, could resulting in being a victim of various activities such as fraud and aggressive advertisement. Jordanians people are not legally educated, as most of them are not aware of the legal framework that governs electronic commerce. On the other hand, even if people are aware of the existence of this law, the ETL itself were drafted in a very complex way. This also points to the limitation of this law as the model transaction law has been literally translated. The law used purely legal terms and jargons which make it difficult to understand by the non-special reader, also without giving any consideration to the terms used in the Jordanian market. 
Researcher 3: "Jordanians have uncertainty and they have a very big problem regarding awareness, also there is a problem regarding the legal education"

Laws in Jordan are usually endorsed by the House of parliament after a series of procedures, then they will be published in the Official Gazette, and after 30 days these laws become legitimate. However, in Jordan, there are many people who do not read the Official Gazette. Therefore, the role of universities and schools become significantly important to announce these laws. In addition, the use of television advertisements where that Jordanian citizen become aware what are the laws, which gives them a series of rights and duties.

Furthermore, if the Jordanian government interested in the success of e-commerce as they did to ensure the successful of e-government, it must use the same methods used to educate people through television advertisements and applications. What is needed from the government is to produce at least one application that aims to make people aware of electronic commerce in general and the legislation in particular. This will action will make a big shift in the development of electronic commerce in Jordan.

\subsubsection{Successful Practices}

There is no doubt that the existence of ecommerce law will enhance the development of ecommerce implementation and adoption in any country. The UNCITRAL law issued a model online transaction law so all countries around the world can follow to ensure that there is no conflict of laws, especially because e-commerce is an international and borderless in nature.

Therefore, there had to be an agreement of laws to create some sort of harmony in the rules that govern e-commerce. The ETL in Jordan is an important aspect in order to recognise the existence of e-commerce. However, this law has a lot of limitations, as some rules governing the relationship between parties who are contracting electronically are not detailedly clarified. Consequently, all the rules governing the contract will be turned back to the general rules in civil law.

Jordan has an opportunity to borrow from other countries that already have established laws governing internet businesses such as the USA and UK. In these developed nations, the consumer is protected through adequate regulations that govern how online stores should be established and how internet service providers should operate. By referring to these models, Jordan stands to benefit by instituting adequate relevant laws that apply to their situation without having to use many resources in extensive research. The nature of online transactions is quite different from other transactions in several ways.
Firstly, the parties involved carry out their transaction at a distance from each other, unlike other transactions where they are located in one place. Lack of this physical presence gives rise to certain concerns thus requiring regulation to protect the parties. Secondly, online transactions involve added risk to the buyer compared to the traditional transaction settings. For example, in a traditional setting, the buyer is physically present at the store and has the opportunity to examine the product before making a purchase. This is usually not the case in an online transaction. This calls for legislation that can protect the buyer in the event of a contract where the seller took advantage of the circumstance to defraud the buyer, or vice-versa. To encourage e-commerce in Jordan, the Jordanian legislature should ensure both businesses and customers are adequately protected and are aware of the protection afforded him/her.

Legislation has a crucial role and it consists of combinations of elements. Therefore, each element of law required to achieve an objective, and this objective cannot be achieved by e-commerce law only, but there are a set of laws that should be endorsed to be full-fledged. Therefore, Jordanian legislator required not to make the same mistake by issuing electronic consumer protection law where there is an absence of the consumer protection law in the traditional environment, where the customer can trust the traditional market in the first place and being confidence to transition to electronic market. On the other hand, the successful Self-Regulation model which was adopted by "E-Bay" to ensure consumer protection could be a decent option that the legislator can force online businesses to adopt it. Thus, this will increase the consumer protection by providing refund policies and various payment options. This will cover most of the limitations that the ETL failed to include.

\subsection{Economical Barriers}

\subsubsection{Lack of Postal Services}

Development of postal services in a country affects the rate of e-commerce growth. This is because most of the e-commerce products rely on postal services to facilitate their operation such as delivery of parcels, bills, and transactional documents [26]. In this respect, postal operators all over the world are quickly advancing their services to accommodate crucial ICT solutions that support ecommerce. This includes integrating payment and parcel tracking services in their ICT systems and offering solutions to counter the increasing problem of illegal and counterfeit products originating from ecommerce.

Jordan is considered to be adequately high in terms of technical preparedness and professional 
preparedness. However, it is still in an earlier stage of developing some services. One of these services is the Jordanian postal system which runs by the government. The postal service is underdeveloped as compared to first world country standards, but quite adequate to offer basic postal services to the country's' customers. Services offered include money transfer, mail and parcel delivery through rental post office boxes [27].

In Jordan, the delivery system does not include door step delivery, as there is no associated address to the streets and homes in most of the cities, which makes it difficult for e-commerce business to effectively serve their customers. Since the mail is still handled manually, most people pick up their mail from post offices [26]. This operating environment is counterproductive for the growth of a new age system such as e-commerce which relies heavily on access to information of customers. The lack of an efficient postal system is equally detrimental to customers as well. For e-commerce customers, the delivery system is an important service in order to get their products on time and at a fair price.

However, when it comes to accesses to ecommerce services, customers in Jordan are still facing two major issues: 1) lack of an assigned home address, 2) some businesses do not post their products to specific countries. This makes it challenging for customers to take advantage of ecommerce services even if they are aware of its benefits.

Delivery Agent A 1: We have a post office in each city in Jordan, customers can rent a PostBox and get his/her mails delivered to it. We usually notify our customers by calling them or sending text messages to collect their postage from their local post office.

Delivery Agent B 2 and C: Customers usually provides their contact details and city address in their orders, therefore, we usually call the customer to arrange the delivery to their most convenient place. often customer's direct us to their existing place to get their postage.

Lack of an assigned home address is not only limited to Jordan, where most of developing countries are faced with the same issue. Since allocating associated address to every home in Jordan seems to be difficult as this stage, as this will require a vast of resources and planning and above all, it cannot be achieved overnight. Therefore, the two alternative options provided by the delivery agents can to some extent wave this challenge. This will ensure the customers that their postages will be delivered to them anytime and anywhere in Jordan.

Secondly, some businesses do not post their products to specific countries. Customers in Jordan are facing another type of challenge, even though they are extremely interested in e-commerce services, the weaknesses in supplemental systems prevent them from using e-commerce like their counterparts in other countries. Some businesses are only posting their products to specific countries or regions, and Amazon is one of them. Jordanian are well introducing to some well-known online shopping sites but their engagement was not present due to the delivery barrier. Therefore, the role of delivery agents had to be present in solving this issue.

Delivery Agent B 2 and C: We understand that some customers cannot have their products deliver to them due to their location and Jordan is one of them. Therefore, we offered our customers to open a virtual account in any country that allows them to have their products delivered, then when their products delivered to that address we ship it to Jordan.

The previous statement provided by privet delivery agents could be a proper solution for customers who are willing to shop online from businesses that not shipping to certain countries. However, this challenge remains with the service high cost, as most of the customers they do not afford the shipping cost added to their purchase. Therefore, a new solution should be found to overcome this issue.

Awareness in e-commerce plays an important role in its adoption. Each process in e-commerce cycle requires a certain level of awareness to successfully complete the purchase online. Therefore, awareness of the delivery services available to the customers is an important aspect. Customers need to distinguish between the affordable and sufficient delivery service available to him/her. Online businesses are responsible for posting information about their products and shipping information, while customers have the options to choose the convenient shopping service. Therefore, customers should have a certain level of awareness to complete their purchase.

\subsubsection{Lack of Payment Systems}

The diffusion of the Internet has radically changed the financial services industry. Many banks have established a presence on the Internet using web technologies providing customers with the opportunity of performing transactions by various means [28]. The availability of reliable payment systems such as debit and credit cards provided by financial sector like banks that facilitates the online payment transactions is critical to the development of e-commerce in especially in the developing countries [29].

Such service makes the payment over the Internet possible through credit, debit, or digital money. It also facilitates other transactions conducted online like delivery of those products purchased over the Internet. Its development also requires reliable and secure payment infrastructure to avoid frauds and other illegal actions. A supportive electronic 
payments infrastructure is crucial to ensure the success of e-commerce, which considers a bridge between e-commerce and the financial firms of the economy. The efficiency and availability of the payments system itself can help or hinder the development of e-commerce.

In most developing countries, customers may be unable to purchase online because most of them do not own credit cards. In addition, many firms in the developing countries do not have payments systems that are available to make online shopping [13]. Previous studies have found such problem for B2C e-commerce in Russia, India and Latin America [30]; [31]. In Asia, 35-40\% of transactions are cash-based [32]. Other aspects of financial systems are also underdeveloped [33]. In the Caribbean, local banks do not process online credit card transactions or other forms of electronic payment systems [34]; [35]. Similarly, in China lack of online payment processes directly inhibit e-commerce [36]. The banking sector in Jordan is not an expectation to this challenge, it is yet to be fully utilised as a value-adding tool to improve customer relationships and achieve cost advantages. Unavailability of credit cards is also a major hurdle in Jordan [37]; [38]; [32]. However, most banks in Jordan allow their customers to use their cards to purchase online upon activating their cards in advance, but there are certain rules and procedures. According to interviewee A, "There are two types of cards available to our customers: Visa Electronic cards and Charged cards (Credit Card), both cards authorised its holder to make online payments but he/she have to activate in advance.

Banks and payment gateways were aware of the trust issue, especially within the Jordanian culture. Therefore, to reduce the possible exposure to theft and fraud allowed with debit and charged card, they provided an alternate solution for those who are willing to shop online without the need to exposed their card details. Interviewee B and C stated, "Recently, we started to issue an online shopping card called (Pre-Paid Shopping Card) which allows any existing clients and non-clients to deposit a certain amount of money in advance to use this card with some additional fees We believe customers will feel confident this way." Interviewee C said "we had to think of having online payment options to build the trust and encourage our customers to buy online, otherwise, this will affect the decision to adopt ecommerce"

Despite the solutions offered by banks and payment gateways, customers in Jordan still not aware about these services. Lack of awareness in payment systems has created a barrier to e-commerce adoption. Therefore, service providers should follow an awareness strategic plan to utilise and create a greater potential for their customers to participate in e-commerce. Interviewee A explained the reason for E-Commerce not being used widely is that "In
Jordan, there is insufficient awareness and understanding of E-Commerce services". Thus, awareness of online payments is crucial for successful e-commerce adoption in Jordan and developing countries in general.

\subsection{Sociocultural Barriers}

\subsubsection{Lack of E-commerce Awareness}

In most developing countries, sociocultural characteristics associated with e-commerce pose a challenge and consider as a major barrier to ecommerce development. Lack of e-commerce awareness is the most critical inhibitor cultural barrier which prevents customers to engage in ecommerce. According [13], lack of e-commerce awareness is a factor taken for granted in developed countries. Awareness about all aspect of e-commerce is important to ensure the success of e-commerce adoption.

Customers need to be aware of the availability of services they can choose while shopping online. For example: what are the payment and delivery options available to them?, what their right and what are the laws that ensure their protection. By acknowledging those elements, customers become familiar with ecommerce hence it enhances the chance to adopt ecommerce. According to [39] argued that awareness about e-commerce and its benefits is an important initial stage that may affect the decision to adopt or reject the adoption. Once a customer has become aware of the potential of e-commerce he/she will make the decision to shop online.

Lack of e-commerce awareness among customers was found in most of the Middle Eastern countries such as Saudi Arabia, Jordan [40]; [41]; [42], and other developing countries like India and China [43]; [44]. Furthermore, awareness of e-commerce has received high attention by many interviewees. They consider it as an essential solution toward ecommerce adoption. The interviewee A, a researcher in e-commerce law stated: "customers need to be aware of the advantages of adopting e-commerce, but this cannot be done without a collaborate effort from e-commerce decision makers such as government, banks, and privet businesses". Therefore, to achieve this, interviewees B, C, and D have suggested that "There has to be a strategic plan to promote all aspect of e-commerce to make customs aware of how e-commerce works and what its benefits are. Customers must be aware what are the legal issues concerning e-commerce, how to pay for their products and services, and finally how they can get their purchases". 


\section{Conclusion}

Ecommerce success is a collectively participatory process, where all stakeholders involved in developing that success and sustain it. Success in electronic commerce is relatively contextual, and based on a number of factors. The vast majority of Jordanian electronic commerce literature has dealt with aspects related to measuring the current electronic commerce processes based on universal success metrics, this is not necessarily the only way to measure a technological, commercial and social phenomenon such as electronic commerce. Having clearly defined success models begins with identifying the current context limitations that could slow down the ecommerce uptake, when this is accompanied with a stakeholder analysis, it should help to create a road map of involvement with explicit roles and responsibilities.

Technology is a key factor to electronic commerce success, and has always been thought of as the main driver to success, however, this research shows that it is not the only driver, awareness and understanding different electronic commerce processes can greatly help in pushing towards that success.

This paper has moved away from the universal measurement model of electronic commerce, and it provides different insights into how perceptions and awareness, along with other factors and limitations, can lead to better understanding of the context and help in clearing all stakeholders take in developing a successful model. When sociocultural and legal limitations are combined with better awareness, a new perspective has emerged, to realize that the problem of electronic commerce adoption goes beyond technology.

\section{References}

[1] Daud Norzaidi, M., Choy Chong, S., Murali, R., \& Intan Salwani, M. (2007). Intranet usage and managers' performance in the port industry. Industrial Management \& Data Systems, 107(8), 1227-1250.

[2] Internet World Stats, (2016). Internet usage statistics and Internet users in the world distribution by world region Available at: http://www.internetworldstats.com/stats.htm

[3] Jaradat, M. I. R. M., \& Faqih, K. M. (2014). Investigating the moderating effects of gender and selfefficacy in the context of mobile payment adoption: A developing country perspective. International Journal of Business and Management, 9(11), 147.

[4] Alyoubi, A. A. (2015). E-commerce in developing countries and how to develop them during the introduction of modern systems. Procedia Computer Science, 65, 479483.
[5] Paré, D. J. (2002). B2B e-commerce services and developing countries: disentangling Myth from reality. In International Conference on Internet Research (Vol. 3, pp. 13-16).

[6] Humphrey, J., Mansell, R., Paré, D., \& Schmitz, H. (2003). Reality of e-commerce with developing countries, London: Media Studies, LSE.

[7] Yaseen, H., Dingley, K., \& Adams, C. (2016). Capturing the Growth of E-Commerce in Jordan Using a Novel Research Approach. International Journal Of Management And Commerce Innovations, 3(2), 811-827.

[8] Al-Shboul, M. A., \& Alsmadi, I. M. (2010). Building an e-Commerce Infrastructure in Jordan: Challenges and Requirements. International Journal of Interactive Mobile Technologies (iJIM), 4(4), 18-24.

[9] Abu-Shamaa, R., \& Abu-Shanab, E. (2015). Factors influencing the intention to buy from online stores: An empirical study in Jordan. In GCC Conference and Exhibition (GCCCE), 2015 IEEE 8th (pp. 1-6). IEEE.

[10] Neuman, L. W. (2002). Social research methods: Qualitative and quantitative approaches. 6th ed. 2006, Boston, MA: Pearson Education.

[11] King, J. L., Gurbaxani, V., Kraemer, K. L., McFarlan, F. W., Raman, K. S., \& Yap, C. S. (1994). Institutional factors in information technology innovation. Information systems research, 5(2), 139-169.

[12] Molla, A. (2005). Exploring the reality of e-commerce benefits among businesses in a developing country. Working Paper No. 22, University of Manchester. Institute for development policy and management (IDPM).

[13] Molla, A., \& Licker, P. S. (2005). eCommerce adoption in developing countries: a model and instrument. Information \& management, 42(6), 877-899.

[14] Khalfan, A. M., \& Alshawaf, A. (2004). Adoption and implementation problems of e-banking: a study of the managerial perspective of the banking industry in Oman. Journal of Global Information Technology Management, 7(1), 47-64.

[15] AlGhamdi, R., Drew, S. and Alkhalaf, S. (2012). Government initiatives: The missing key for e-commerce growth in KSA. In International Conference on eCommerce, e-Business and e-Service, 77(3), 772-775. Paris, France.

[16] Halaweh, M., \& Fidler, C. (2008). Security perception in e-commerce: Conflict between customer and organizational perspectives. In Computer Science and Information Technology, 2008. IMCSIT 2008. International Multiconference on (pp. 443-449). IEEE.

[17] AlGhamdi, R., Drew, S. and Al-Ghaith, W. (2011), "Factors influencing e-commerce adoption by retailers in Saudi-Arabia: A qualitative analysis", The Electronic 
Journal of Information Systems in Developing Countries, 47.

[18] Al-Qirim, N. (2006), "The role of the government and E-Commerce adoption in small businesses in New Zealand", International Journal of Internet and Enterprise Management, Vol. 4, No. 4, pp. 293-313.

[19] Kurnia, S. (2006, July). E-commerce adoption in developing countries: an Indonesian study. In San Diego international systems conference (pp. 14-16).

[20] Nasco, S.A., Toledo, E.G. and Mykytyn, P.P. (2008), "Predicting electronic commerce adoption in Chilean SMEs", Journal of Business Research, Vol. 61 No. 6, pp. 697-705.

[21] Papazafeiropoulou, A. (2004). Inter-country analysis of electronic commerce adoption in South Eastern Europe: Policy recommendations for the region. Journal of Global Information Technology Management, 7(2), 54-69.

[22] Chan, B., \& Al-Hawamdeh, S. (2002). The development of e-commerce in Singapore: The impact of government initiatives. Business process management journal, 8(3), 278-288.

[23] Al-Weshah, G.A. and Al-Zubi, K. (2012), "E-business enablers and barriers: empirical study of SMEs in Jordanian communication sector", Global Journal of Business Research, Vol. 6 No. 3, pp. 1-15.

[24] Yaseen, H., Dingley, K., \& Adams, C. (2015). The government's role in raising awareness towards ecommerce adoption: the case of Jordan. In Proceedings of the 15th European Conference on eGovernment (p. 316).

[25] Al-Ibraheem, M., and Tahat, H. (2006), "Regulating electronic contracting in Jordan", In 21st BILETA Conference, Malta, pp. 6-19.

[26] Dayan, E. (2012). Introduction: MENAP B2C eCommerce Review 2012, London: Interactive Media in Retail Group.

[27] Jordan Post, 2009. Our History.Available at: http://jordanpost.com.jo/?page_id=5

[28] Aladwani, A.M., (2001). Online banking: a field study of drivers, development challenges, and expectations. International Journal of Information Management 21 (3), 213-225.

[29] Oxley, J. E., and Yeung, B., (2001), E-Commerce Readiness: Institutional Environment and International Competitiveness, Journal of International Business Studies, Vol. 32, No. 4, pp. 705-723.

[30] Hawk, S. (2004). A comparison of B2C e-commerce in developing countries. Electronic Commerce Research, 4(3), 181-199.
[31] Hilbert, M. R. (2001). Latin America on its path into the digital age: where are we? United Nations Publications.

[32] Biederman, D. (2000). Ecommerce comes to Asia. Traffic World, 26(9), 23.

[33] Kenny, C. (2003). The Internet and economic growth in less-developed countries: A case of managing expectations?. Oxford Development Studies, 31(1), 99113.

[34] Fraser, S., \& Wresch, W. (2005). National competitive advantage in e-commerce efforts: A report from five caribbean nations. Perspectives on Global Development and Technology, 4(1), 27-44.

[35] Wresch, W., \& Fraser, S. (2006). Managerial strategies used to overcome technological hurdles: a review of e-commerce efforts used by innovative Caribbean managers. Journal of Global Information Management, 14(3), 1.

[36] Kapurubandara, M. (2009). A framework to etransform SMEs in developing countries. The Electronic Journal of Information Systems in Developing Countries, 39.

[37] Mercer, C. (2006). Telecentres and transformations: Modernizing Tanzania through the Internet. African Affairs, 105(419), 243-264.

[38] Kenny, C. (2003). Development's false divide. Foreign Policy, (134), 76.

[39] Rogers, E. M. (2003). Elements of diffusion. Diffusion of innovations, 5, 1-38.

[40] Al Nagi, E., \& Hamdan, M. (2009). Computerization and e-Government implementation in Jordan: Challenges, obstacles and successes. Government Information Quarterly, 26(4), 577-583.

[41] Zeglat, D., \& Alzawahreh, A. (2012). The importance of trust and security issues in e-commerce adoption in the Arab World. European Journal of Economics, Finance and Administrative Sciences, 52, 172-178.

[42] Yaseen. H, Dingley. K, and Adams. C, "An Empirical Study of Factors Influencing E-Commerce Customers' Awareness in Jordan," The International Conference on Information Society (i-Society) - Technical Co-Sponsored by IEEE UK/RI Computer Chapter, 18(24), 63. Dublin, Ireland

[43] Ghobakhloo, M., Arias-Aranda, D., \& BenitezAmado, J. (2011). Adoption of e-commerce applications in SMEs. Industrial Management \& Data Systems, 111(8), 1238-1269.

[44] Lawrence, J. E., \& Tar, U. A. (2010). Barriers to ecommerce in developing countries. Information, society and justice journal, 3(1), 23-35. 